\title{
BACK TO GOIÁS AND MINAS GERAIS: Returnees, Geographical Imaginations and its Discontents
}

\begin{abstract}
Alan Patrick Marcus
Abstract

Migration processes to the United States are just as much about those migrants who leave Brazil as it is about those who remain, and also about those who return to Brazil (i.e.; returnees). Brazilian immigration to the United States is a relatively recent phenomenon that gained momentum in the 1980s in unprecedented numbers. How are these Portuguese-speaking Brazilian immigrants shaping and (re)creating new places and spaces, and what happens upon their eventual return to Brazil? How are migrant returnees experiencing changes in their livelihoods in two sending communities in Brazil, after living in two receiving communities in the United States? Using multiple methods and selected extracts from 273 in-depth and informal interviews, this paper addresses these questions by evaluating the changes incurred by migration. Brazilians (re)create transnational places and spaces through social, cultural, and economic practices, within receiving communities, but they also incorporate and add new elements to their livelihoods in sending communities of Piracanjuba, in the state of Goiás, and Governador Valadares, in the state of Minas Gerais, in Brazil. Brazilian migration processes have both positive and negative ramifications. However, the migration process is experienced differently by men and women. Men tend to experience an emasculation of sorts and are happier in Brazil, while women tend to indicate higher happiness levels in the United States.
\end{abstract}

Keywords: Brazilian immigration. Return migration. Transnationalism. Cultural geography. Ethnic geography.

\section{Introduction}

Recently ethnic geographers have observed how the influx of recent immigrants to the United States in the past four decades has significantly transformed U.S. ethnic landscapes and economies in various spatial and sociocultural ways (BERRY AND HENDERSON 2003; FRAZIER AND TETTEY-FIO 2006; KAPLAN AND LI 2006; MIYARES AND AIRRESS 2007). Brazilian immigrants are second among the three largest U.S. unauthorized population percent increases from 2000 to 2006, with an average annual population change of 110

\footnotetext{
* Doutor em Geografia. Professor da Universidade de Towson, EUA. E-mail: amarcus@towson.edu
} 
percent (U.S. DEPARTMENT OF HOMELAND SECURITY 2005, 2006). Today an estimated 1.2 million Brazilians live in the United States (BRAZILIAN MINISTRY OF FOREIGN AFFAIRS 2006), yet the U.S. Census 2000 counted only 212,428 Brazilians (U.S. CENSUS 2000A, 2000B), and the American Community Survey in 2007 counted a little over 300,000 (ACS 2007). However, because of unbalanced emphasis placed on Spanish-speaking America (See Marcus 2008), not only within academia in general but disseminated within U.S. public discourses, Brazilian Diasporas are rendered invisible (MARGOLIS 1994, 1995, 1998), and remain largely unknown to the general U.S. public (despite efforts for example, of FALCONI AND MAZZOTI 2007).

These migration processes have also shaped new economic and sociocultural landscapes in two Brazilian sending communities of Governador Valadares (Minas Gerais), and Pirancanjuba (Goiás). For example, when the exchange-rate of the Brazilian Real to the U.S. Dollar recently reached a peak low in August 2007, at a rate of RS\$1.94 to the U.S. Dollar, twenty-five cities in the region of Governador Valadares felt the economic impact, and experienced a significant halt in the real estate sectors and in local investments (MOREIRA 2007). Brazilian immigrants sent US\$6 billion in remittances back to Brazil in 2004, representing about one percent of the Brazilian Gross Domestic Product (GDP). However, because most of these remittances were sent informally, the Brazilian Central Bank (Banco Central) officially registered only US\$2.4 million in remittances for the same year (MARTES AND SOARES 2006). These transactions represent important examples of transnational exchange flows, linking communities across borders, driving the broader concept of transnationalism (e.g.; BASCH ET AL.1995; TSUDA 1999; LEVITT 2000, 2004, 2007). ${ }^{1}$ Brazilian immigrants send monthly financial remittances ranging from US $\$ 500$ to US $\$ 1,000$ back to their sending communities (SIQUEIRA 2006, p.25). Entire communities have become dependent on these remittances - locals call it: Vala-dollar (U.S. Dollar remittances to Governador Valadares). When the U.S. Dollar exchange-rate decreases, economic ripple effects are felt throughout those sending communities generating financial stagnation and resulting in a generalized local crisis (MOREIRA 2007). These examples illustrate the broader impact of transnational interactions affecting local economies across formal borders.

I draw upon theoretical perspectives based on previous research on Brazilian immigration to the United States (e.g.; MARGOLIS 1994, 1995, 1998; SALES 1998; GOZA

\footnotetext{
${ }^{1}$ Transnational approaches focus on the significance of ongoing immigrants' ties and loyalties to country of origin, and how they are generated and maintained through various spatial, sociocultural, and financial processes.
} 
1999; MARTES 2000; MARROW 2003, 2004; ALMEIDA 2003; BESERRA 2003; MARTES AND SOARES 2006; SIQUEIRA 2006). I use a transnational theoretical approach to evaluate how these connections and exchanges occur across formal territories, and more importantly, to understand what happens to returnees (i.e.; their experiences and livelihoods) and to those sending communities in Brazil. Finally, I explore how men and women experience migration processes differently, and how men tended to be less happy when they lived in the United States than women.

Within these two sending communities, migration processes have also produced a dimension of "discontents" of sorts, directly tied to the culture of migration. For example, family fragmentation is emblematic. I talked to a restaurant cashier at a restaurant in Governador Valadares. He explained why he hated the United States:

It destroys families. It destroyed mine. Usually it's the man that leaves, but in my case, it was my wife, now "ex.” She had left to the United States, well... something else happened [deu em outra coisa]. But at least my son is with me...you know many families are destroyed because of this...

Local elites stand to gain financially and politically from human smuggling and the out-migration phenomena. This type of asymmetrical financial gains in sending communities illustrates the broader dimension of the localized "discontent" generated by migration processes. A local scholar in Governador Valadares observed: "Brazilians are not criminals but workers...the consul is the real criminal and the drug-trafficker.” Consuls are individuals who arrange the entire trip to the United States for a fee of $\$ 12,000$ to $\$ 15,000$. They enjoy the highest socioeconomic levels in Governador Valadares, with newly built houses on the hills (some are worth over \$1 million in value).

\section{Methods}

I conducted fieldwork in four locations and two countries: (a) Framingham, Massachusetts; and (b) Marietta, Georgia, United States; and, (c) Governador Valadares, in the state of Minas Gerais; and, (d) Piracanjuba, in the state of Goiás, Brazil. I used: participant observation; results from a survey instrument in 100 interviews (25 in each place); Brazilian and U.S. Yellow Pages; and, for this paper, I use selected extracts (vignettes) from 173 informal unstructured interviews (66 in Brazil and 107 in the United States) and from 100 formal interviews - from a total of 273 interviews. I selected Governador Valadares and 
Framingham because of their status as traditional sending/receiving communities (and wellestablished in the literature), and Piracanjuba and Marietta as a new migration corridor and unstudied until now. The city of Governador Valadares is one of the oldest sending communities in Brazil, with migrants leaving mainly to destinations in Massachusetts, New York, Florida, California, and Connecticut, (ALMEIDA 1999; BESERRA 2003; LEVITT 2007; MARGOLIS 1994, 1998; MARTES 2000; SALES 1998; SIQUEIRA 2006). I conducted exploratory research in Piracanjuba, and found out that most interviewees were either returnees themselves, or they had family members and/or loved ones residing in the United States, mainly in Marietta or the Greater Atlanta area. Hence my snowball sample in Marietta and Piracanjuba opened up valuable research opportunities, and later, I selected both as research sites. I also wanted to evaluate spatial and socioeconomic inter-relationships, particularly in two distinct U.S. destination regions (U.S. Northeast and U.S. South).

All returnees I interviewed were born and raised in their respective sending communities. I interviewed slightly more women (51percent) than men (49 percent). The average age of all interviewees was 42 (ages ranged from 18 to 74 years of age), and, I did not interview minors (under eighteen years of age) or mentally incompetent subjects. The average length of stay in the United States for all Brazilian migrants interviewed was seven years. Immigrants who remained in the United States had been in the country, an average of ten years, while returnees' average length of stay was five years. I used a "snowball sampling” technique (See MARGOLIS 1994, p. xxi). Therefore, this study has its inherent limitations, as it was not intended to be a representation of all Brazilians immigrants in the United States or of all returnees in Brazil. The aim was to evaluate at the micro-level, how migration processes between two "migration corridors" - an older one between Governador Valadares and Framingham, and a more recent one between Piracanjuba and Marietta - have shaped, and shape place perceptions and experiences- that is, I evaluate transnational ways in which migrants have (re)created places and spaces within the migration process. Site selection was based on these migration corridors.

\section{Re-Thinking Emigration in Sending Communities}

There is a tendency in sending communities to perceive Brazilian migrants as "heroes." In fact, the mayor's office of Governador Valadares has inserted a plaque in a major city plaza, treating emigrants as "heroes.” It reads: “The tribute to emigrants brings 
justice to the dignified work of these heroes for their contribution to the development of Governador Valadares.” The unlikely date of the plaque inauguration, July 4, coincides with the city's official Dia do Emigrante (“Day of the Emigrant”). The general societal notion that Brazilian emigrants will bring some type of “dignified” benefit to Brazilian society and to the Brazilian economy suggests strategic maneuvering on the part of local elites, who continue to benefit financially and, at the same time, divert the broader economic and social problems Brazil currently faces. The ascription of "hero," in this case, only perpetuates the lure of emigrating abroad, as well as it sustains the dependency on financial remittances for local developments and investments sent from migrants abroad. This financial dependency overshadows local, regional, social and ecological problems, as well as the economic upheavals in Brazil. It sustains a continual seduction - the geographical imagination - to emigrate abroad. This seduction has produced a "culture of out-migration" fettered to the chains of unrealistic financial expectations, and propelled by geographical imaginations (MARCUS 2009a, 2009b). Brazilian governments at all levels may use this lure to their political as well as financial advantage. That is, the benefits reaped from some migrant's financial remittances obfuscate local, state, or federal predicaments.

In order to break the cycles of co-dependency of out-migration, local community leaders in Governador Valadares and Piracanjuba conveyed to me the need to focus on locally-based projects to retain its scarce labor force and sustain its tenuous socioeconomic and ecological circumstances. Such efforts have already begun in Governador Valadares with the recent creation of three local organizations which have addressed the challenges faced by returnees when they return to their home communities in Brazil. Since their inception in 2006, the three organizations do not agree on common political grounds. In fact there is visible friction between them. One of the leaders said, "We must find an alternative to [financial] remittances." Another organization leader also re-iterated this sentiment, "The mayor is desperate. The city has been transformed by remittances, but now with the fall of the [U.S.] Dollar, the economy is being smashed...the only ones who profit are those who deal with human smuggling.”

Carlos, a local community activist, heads an organization called "Retorno," in Governador Valadares, which began in 2006, partially financed by a federal bank and by the workers' union. Their goal is to protect the local labor force by developing local sources of income instead of relying on emigration as a solution, or on remittances. He tells me that outmigration is a "cultural habit" and the most expressive regional phenomena in the last 10 
years, as local politicians actively finance and support these migration movements. He explains:

There are children without parents, because the parents are all out of the country, and the separation from the family creates emotional problems. We need to create an environment that facilitates the return, the value of place of origin. We are intimately tied to local culture and we see an unsustainable pattern, directly driving emigration and dependency without our own local development.

Carlos told me about 72 rural communities in the region, 12 districts, and 64 urban conglomerates where there "are only grandparents, grandchildren and women, because all of the male manual labor has gone away...We are seeing that there is an emotional problem...the communities are fragmented emotionally.” He feels that migration does not resolve the social problem, but only compounds it: "there is a local culture of emigration as a sole source of income. We need to position ourselves from a local perspective for better development.”

Cunha heads another organization, called "Porto," based at the mayor's office in Governador Valadares, which also works specifically with issues pertaining to returnees and immigration. He explained that the mayor's office does not have legislative power in international relations, but because of increasing emigration problems and demands from local families to help with problems that arise with ex-patriots abroad. Cunha noted that "Retorno" finds itself in political conflict with public policy platforms advocated by "Porto," because of its leftist political platform. He explained:

Its character is to only assist the emigrant. Our spaces are not tied to party politics. Our Porto has a reception desk, open to the public, we will train to provide local skills for those entering the manual labor market, and we will have courses for electricians, construction workers, commerce, hotel, and return-tourism for those Brazilian emigrants returning for tourism.

Cunha informed me of the problem when returnees purchase one or two apartments to rent and expect to live from the rent; however, he states that the market does support these real estate transactions, and, according to him, it occurs because of the lack of orientation of returnees: "That is why we created Porto in 2006, to show how and where to invest locally.”

\section{Experiencing the Return}


Returnees often face challenges upon their return to Brazil. For example, Bosco, age 33, and a returnee in Piracanjuba had paid US\$12,000 to cross into the U.S. territory. When he returned to Brazil, he bought a car and furniture for his house - as returnees commonly do by engaging in conspicuous consumption to avoid the local social stigma of been perceived as “failures” in their journey as immigrants. He worked on swimming pools in Marietta, making an average of US\$1,200 weekly, working a six-day week, 12 to 15 hours daily. He told me that he never left cash in his apartment for fear that somebody might steal it, so he would carry sums of up to US\$3,000 wrapped in a plastic bag in his pocket every day when he worked, until ultimately wiring it back to Brazil. His descriptions about cash exchange provide important glimpses into the magnitude of global money transfers:

At one time I had US\$6,000 in my pocket...I would wrap it in a plastic bag so it wouldn’t get ruined by my sweat. Other Brazilians typically carry $\$ 2,000$ in their pockets, until they wire it back to Brazil. My friend once saved $\$ 100,000$ in cash in the apartment. I didn't save that much, because I always sent my money back to Brazil: US\$2,000 to US\$3,000 with a local remittance service.

After Bosco returned to Piracanjuba, he had no intentions of returning to the United States for a second time, but the standard of living had increased for him and his family as they had made so many purchases, buying new furniture, cars, and clothes, and now they needed to maintain this standard of living. His second trip to the United States exacerbated marital conflicts, eventually prompting Bosco to return to Brazil in order to save his marriage. Now he works for a local grain company and told me, "I was glad to have experienced America, but keeping my family was more important.” Another returnee in Governador Valadares, told me about his conflicting feelings about returning:

The advantages here, is human warmth, the Brazilian warmth. But here there is not one playground or park to take the family on a weekend! I have a deep desire to return to the U.S. - I learned with the American life-style (Didi, 42 years old)

The conflicting feelings about returning to Brazil and the lack of human warmth among Americans were recurring themes among returnees. However, Duarte, age 34, also from Governador Valadares, was not conflicted, in fact he wanted to stay: "When I first returned to Brazil it was a shock. I found everything dirty and backward. Here the government does not invest in sanitation.” Below there is an extract from a returnee in 
Piracanjuba, illustrating broader notions of cultural, racial and gender roles and geographical imaginations in the migration process:

You get the types who come from the rural areas here [matuto da roça], and who have not even been to Goiânia. Women once they are there, get together with whoever they want...they are worst than blacks when they have money! It was a relief to return to my own country...my language. I was in the wild without a dog! [fiquei no mato sem cachorro!]. Brazilians have no manners...they throw things onto the street. I learned from Americans. (Lucio, 54 years old)

\section{Migrant Experiences: Differences between Women and Men}

My husband's dream was to return to Brazil...so he could take his naps on the hammock and watch the townsfolk pass by. But the women like it here (Barbara from Minas Gerais, age 53, housecleaner in Marietta).

Until recently, immigration studies tended to ignore women, or to portray them as mere passive followers of male immigrants. Today women, in some cases, outnumber men, such as Southeast Asians (CASTLES AND MILLER 2003) and Caribbean immigrants, to the United States (BRETTELL 1999, p. 109). Castles and Miller have spoken in terms of the "feminization of migration" and how the awareness of women in migration studies has grown since the 1960s, as well as how women play a significant role in all types of migrations (2003, p. 9). In this case, Brazilian women have gained important financial and social empowerment in the housecleaning sector, and have become key actors in generating and maintaining social networks in both sending and receiving communities (Also see: MCDONNELL AND LOURENÇO 2009).

Place perceptions are experienced differently between Brazilian immigrant men and women, however; both men and women in Governador Valadares were relatively happier in Brazil than those in Piracanjuba. For men, these changes tend to be faced with difficulty. Men tend to be unhappier in the United States than their female counterparts. Female empowerment emerges at the cost of a culturally-perceived emasculating component for Brazilian men. This emasculation involves a drastic attack at the concept of "male honor" (See REBHUN 1999). Roberto da Matta (1985) explained the difference between the space/domain of the "street" (rua) - the public domain -, that belongs to men, and the domain of the "home" (casa) - the private domain - that belongs to women. In this case, Brazilian 
women then are inherently passive and belong to the "private domain" (i.e.; the sacred realm of the household) but after immigration occurs, they transgress into the "public domain" (i.e.; the realm of the active and the profane), as they work outside of their homes, often earning more than their husbands. Women are earning money too, which is also perceived as the space of men. Men, on the other hand, who once held total domination over women in Brazil, and who were once exempted from domesticity - a woman's domain - need to transgress into the space of women, and now as immigrants, they need to share domestic chores and responsibilities in the United States. Hence, they become emasculated after immigration occurs. In the Brazilian male psyche, to be effeminate, a homosexual or a corno ("cuckold”), is tantamount to be publicly perceived as “dishonorable,” and to be seen as a failure to live up to the male ideal (PARKER 1991). As a result, this sense of emasculation may play a significant role in domestic violence, family conflict and fragmentation among immigrants and returnees. Since the domain of men is "the street" (rua) (DA MATTA 1985), and, “earning money” also pertains to a man's domain, women who work outside their homes and earn more than their husbands are transgressors, dwelling within the domain only available to men.

Thus after immigration occurs, Brazilian men are positioned in a fundamentally different domain structure, where once they would have been perceived as "less than a man" (i.e.; homosexual, weak, or a corno, “cuckold”), and, therefore, would be perceived as a failure of the ideal male (PARKER 1999). Typically, emasculation involves imbalance between migrant couples' earned incomes, with women financially earning more than men, as well as the changes involved in public behavior and activities, perceived as acceptable to women in the United States - but once only granted to men in Brazil. For example: "Here the goiano men have to become kinder because they know that the woman has more monetary power whereas in Brazil he was machista.” (Mara, age 47, immigrant from Piracanjuba, housecleaning owner, Marietta). When Brazilian immigrants decode new cultural gender scripts and domains within receiving settlements, the cultural spaces where once men and women enacted are suddenly inverted. As Nilva, aged 45, a former housecleaner in Massachusetts, returnee in Piracanjuba, states: "Women have value in the United States."

In conclusion, immigrant men's deeper sense of self is challenged as men, who once had total domination and control over their spouses, are now subject to changes and loss of this control. Many immigrant men find themselves living in the space of women (i.e.; housecleaning, or domestic chores). Along with these changes, and particularly with 
returnees, tension and conflicts occur because of the difficult adaptation to new culturally constructed spaces for men and women.

\section{Concluding Thoughts}

Many of those who remain in the United States long to one day return to Brazil. However, the social stigma of failure is tantamount to being unable to live up to the "migrant ideal” of succeeding abroad. Some return to the United States for a second time, for another four or six year-period, with the intent to save enough money to eventually return to Brazil and purchase a house, an apartment, a car, or start a new business. Some returnees who stay in Brazil reminisce about U.S. cultural values and norms, and wish to return again to the United States, but fear the process of living as an undocumented immigrant. Some returnees are quite happy with their decision to remain in Brazil, and many regret the return to Brazil.

Perceptions of the migrant experience are akin to a "gold-rush" mentality, and in the case of successful returnees, they have indeed found the "gold and brought it back home," as one informant put it. These returnees, who were financially successful and saved enough money, have thus returned triumphantly to their home-towns receiving local accolades for "exploring the unknown wilderness abroad” (desbravando as matas desconhecidas). Their trajectories abroad are embedded within geographical metaphors and tales reminiscent of ancient travelers and mariners from the Age of Exploration. Furthermore, they have fulfilled their curiosity, "reaping the riches" only to return home. Their stories will disseminate throughout sending communities, seducing others who will try their "luck" in this type of migrant experience, diffusing geographical imaginations and enticing further curiosity among those who never left Brazil. Migration processes affect not only those who leave Brazil, and those who remain in sending communities, but also those who return to Brazil (i.e.; returnees). In Brazilian national political spheres, out-migration is mostly discussed in the myopic context of financial and economic gains/losses resulting from migration processes. It is true that financial remittances have benefitted some migrants' families, however; there is a societal price to be paid with human costs that emerge with such benefits, such as high divorce rates, parentless children, and overall family fragmentation. The human cost resulting from migration processes needs to also be included in the equation of adequately gauging net benefits gained from migrants' financial remittances - and particular attention should be given to different ways in which men and women experience the migration process. 
Therefore, Brazilian migration processes have both positive and negative ramifications. However, to perceive financial remittances as the panacea to all Brazilian economic upheavals is misleading and myopic, particularly at the local level. And to perceive economic reasons as the only reasons why Brazilians migrate is equally misleading and narrow in scope.

\section{DE VOLTA PARA GOIÁS E MINAS GERAIS: retornados, imaginações Geográficas e seus descontentamentos}

\section{Resumo}

Processos migratórios para os Estados Unidos são tanto sobre os emigrantes que deixam o Brasil quanto sobre aqueles que ficam, e também sobre aqueles que voltam para o Brasil (os retornados). A imigração brasileira para os Estados Unidos é um fenômeno relativamente recente, que recebeu seu apogeu nos anos 80 com números sem precedência. Como que estes imigrantes brasileiros estão formando e (re)criando novos lugares e espaços, e o que acontece no retorno para o Brasil? Como que os retornados experimentam mudanças em suas vidas em duas comunidades de origem no Brasil depois de terem vivido em duas comunidades de destino nos Estados Unidos? Esse artigo usou extratos selecionados das 273 entrevistas informais e formais (nos dois países), que avaliam as mudanças por causa das migrações. Brasileiros (re)criam espaços transnacionais através de praticas sociais, culturais, e econômicas em lugares de destino, mas também incorporam e adicionam novos elementos em suas vidas em seus lugares de origem em Piracanjuba, Goiás, e Governador Valadares, Minas Gerais. No entanto, homens e mulheres vivenciam diferentemente o processo migratório. Homens tendem a se sentirem emasculados nos Estados Unidos e são mais felizes no Brasil, enquanto mulheres tendem a indicar um índice mais alto de felicidade nos Estados Unidos.

Palavras chave: Imigração brasileira. Retorno. Transnacionalismo. Geografia cultural. Geografia étnica.

\section{Bibliography}

ALMEIDA, Z. M. DE. 2003. Fazer a América: Inserção e Mobilidade do Imigrante Brasileiro em uma Economia de Base Étnica. Minas Gerais, Brazil: Unileste Edições.

AMERICAN COMMUNITIY SURVEY, U.S. CENSUS BUREAU 2007. S0201. Selected Population Profile in the United States, Country of Birth: Brazil; Data Set:

2007:http://factfinder.census.gov/servlet/IPTable?_bm=y\&reg=ACS_2007_1YR_G00_S0201:733;ACS_2007_1YR_G00_S0201PR:733;ACS_2007_1Y R_G00_S0201T:733;ACS_2007_1YR_G00_S0201TPR:733\&qr_name=ACS_2007_1YR_G00_S0201\&-qr_name=ACS_2007_1YR_G00_S0201PR\&qr_name=ACS_2007_1YR_G00_S0201T\&-qr_name=ACS_2007_1YR_G00_S0201TPR\&ds_name=ACS_2007_1YR_G00_\&-TABLE_NAMEX=\&-ci_type=B\&-redoLog=false\&geo_id=01000US\&-format $=\&$-_lang=en 
BASCH, L., N. G. SCHILLER, AND C. S. BLANC. 1995. From Immigrant to Transmigrant: Theorizing Transnational Migration, Anthropological Quartely 6(1): 48-63.

BESERRA, B. 2003. Brazilian Immigrants in the United States: Cultural Imperialism and Social Class. New York: LFB Scholarly Publishing LLC.

BERRY, K. A. AND M. L. HENDERSON (EDS.) 2002. Geographical Identities of Ethnic America. Reno, Nevada: University of Nevada Press.

BRAZILIAN MINISTRY OF FOREIGN RELATIONS 2002. Ministerio de Relações Exteriores. [www.mre.gov.br/portugues/questoes/dowload/rcn2002.xls]

BRETTELL, CAROLYN B. AND JAMES F. HOLLIFIELD (EDS). 1999. Migration Theory: Talking Across Disciplines. New York: Routledge.

BRETTELL, C. B. 1999. Theorizing Migration in Anthropology. The Social Construction of Networks, Identities, Communities, and Globalscapes. In Migration Theory: Talking Across Disciplines, edited by C. B. Brettel and J. F. Hollifield, 109-135. New York: Routledge.

CASTLES, S., AND M. J. MILLER 2003. The Age of Migration. Third Edition. New York: The Guildford Press.

DA MATTA, R. 1985. A Casa e a Rua. Rio de Janeiro Brazil: Editora Brasiliense.

FALCONI, J. L.. AND J. A. MAZZOTI (Eds.) 2007. The Other Latinos. Harvard University David Rockefeller Center for Latin American Studies. Cambridge, Massachusetts: Harvard University Press.

FRAZIER, J. W. AND E. L. TETTY-FIO (Eds) 2006. Race, Ethnicity, and Place in a Changing America. Harpur College, New York, State University of New York at Binghamton: Global Academic Publishing.

GOZA, F. 1999. Brazilian Immigration to Ontario, International Migration, 37(4): 765-799.

KAPLAN, D. H. AND W. LI (Eds). 2006. Landscapes of the Ethnic Economy. Lanham, Maryland: Rowman and Littlefield Publishers.

LEVITT, P. 2001. The Transnational Villagers. Los Angeles and Berkeley: University of California Press.

2004. Transnational Migrants: When “Home” Means More Than One Country, Migration Information Source.

2007. God Needs No Passport. Immigrants and the Changing American Religious Landscape. New York: The New Press.

MARCUS, A. P. 2008. Why so Many Lapses on Brazil and “Latin” America, Association of American Geographers Newsletter Op-ed, October (p.15).

_2009a. (Re)Creating Places and Spaces in Two Countries: Brazilian Transnational

Migration Processes. Journal of Cultural Geography (26) 2: 173-198. 
2009b. Brazilian Immigration to the United States and the Geographical Imagination. Geographical Review 99:4.

MARGOLIS, M. L. 1994. Little Brazil: An Ethnography of Brazilian Immigrants in New York City. Princeton, New Jersey: Princeton University.

1995. Brazilians and the 1990 United States Census: Immigrants, Ethnicity, and the Undercount, Human Organization, 54:52-59

. 1998. An Invisible Minority: Brazilians in New York City. New York: Simon and Schuster.

. 2006. Bibliography of Brazilian Emigration. BRASA (Brazilian American Studies

Association): [www.brasa.org].

MARROW, H. B. 2003. To Be or Not To Be (Hispanic or Latino): Brazilian Racial and Ethnic Identity in the United States Ethnicities (3): 427-64.

2004. Coming to Grips with Race: Second-Generation Brazilians in the United States. A paper presented at the BRASA Congresso Internacional VII, Brazilian Studies Association (BRASA). June 9-12, 2004. Pontifícia Universidade Católica do Rio de Janeiro (PUC-RJ), Rio de Janeiro, Brazil.

MARTES, A. C. B 2000. Brasileiros nos Estados Unidos: um estudo sobre imigrantes em Massachusetts. Brazil: Paz e Terra.

MARTES, A. C. B, AND W. SOARES 2006. Remessas de recursos dos imigrantes, Estudos Avançados 20 (57): 41-54.

MOREIRA, I. 2007. “Dolar a R\$2 gera crise em cidade de MG.” In Valor, Especial, August 28, pp. A16.

McDONNELL, J., and C. de LOURENCO, Cileine 2009. You're Brazilian, right? What kind of Brazilian are you? The racialization of Brazilian immigrant women, Ethnic and Racial Studies, 32(2) 239-256.

MIYARES I. M. and C. A. AIRRIESS (Eds) 2007. Contemporary Ethnic Geographies in America. Lanham, Maryland: Rowman and Littlefield Publishers.

PARKER, R. G. 1991. Bodies, Pleasures, and Passions. Sexual Culture in Contemporary Brazil. Boston, Massachusetts: Beacon Press.

REBHUN, L. 1999. The Heart is Unknown Country. Love in the Changing Economy of Northeast Brazil. Stanford, CA: Stanford University Press.

REEL, M. 2006. Losing Its Young to an American Dream, Men Depart, Dollars Return to Transform A Brazilian City, Washington Post, November 14, 2006; Page A22.

SALES, T. 1998. Brasileiros Longe de Casa. São Paulo, Brazil: Editôra Cortez.

SIQUEIRA, S. 2006. Migrantes e Empreendedorismo na Microregião de Governador Valadares - Sonhos e Frustrações no Retorno. Disertação de doutorado., Ciências Humanas, Sociologia e Política, Universidade Federal de Minas Gerais UFMG, Brasil. 
TSUDA, T. 1999. The Permanence of 'Temporary' Migration: The 'Structural Embededness' of Japanese-Brazilian Immigrant Workers in Japan. The Journal of Asian Studies, 58 (3): 687-722.

U.S. CENSUS BUREAU 2000a. Summary File 3, PCT 19

[http://factfinder.census.gov/servlet/DTTable?_bm=y\&-state=dt\&- ds_name=DEC_2000_SF3_U\&CONTEXT=dt\&-mt_name=DEC_2000_SF3_U_PCT019\&-_caller=geoselect\&-geo_id=01000US\&geo_id=NBSP\&-format=\&-_lang=en]

U.S. CENSUS BUREAU 2000b, Public Law 94,171:

[http://quickfacts.census.gov/qfd/meta/long_68188.htm]

U.S. DEPARTMENT OF HOMELAND SECURITY (Office of Immigration Statistics, Policy Directorate) 2005. Border Apprehensions 2005. Written by Amy Wy:

[www.dhs.gov/xlibrary/assetts/statistics/publications/ois_apprehensions_fs_2005.pdf]

2006. Estimates of the Unauthorized Immigrant Population Residing in the United States: January 2006. Written by Michael Hoefer, Nancy Rytina, and Christopher Campbell: [www.dhs.gov/xlibrary/assets/statistics/publications/ill_pe_2006.pdf] 